\title{
СОСТОЯНИЕ АНТИОКСИДАНТНОЙ СИСТЕМЫ В НЕЙРОНАЛЬНЫХ ТКАНЯХ ГЛАЗА ПРИ МОДЕЛИРОВАНИИ ОФТАЛЬМОГИПЕРТЕНЗИИ У ЖИВОТНЫХ СО СТРЕПТОЗОТОЦИНОВЫМ ДИАБЕТОМ
}

\begin{abstract}
Поиск лекарственных препаратов, направленных на нормализацию обменных процессов в тканях глаза при сахарном диабете и офтальмогипертензии, является крайне актуальным. При этом эффективность лекарственной терапии определяется ее патогенетической направленностью. Поэтому уточнение вопросов патогенеза этих патологий остается по-прежнему важным.

Цель исследования - изучение состояния ферментативной антиоксидантной системы в нервных тканях глаза при моделировании офтальмогипертензии у животных со стрептозотоциновым диабетом.

Материалы и методы. Исследования проводились на 32 кроликах. Подопытные животные были разделены на четыре группы: 1-ая - контрольная группа (8 кроликов); 2-ая - опытная группа, животные с диабетом в условиях гипертензии (10 кроликов); 3-я - опытная группа, животные с диабетом (7 кроликов); 4-ая - опытная группа, животные с гипертензией (7 кроликов). В тканях изолированной сетчатки и зрительного нерва производили определение активности каталазы, супероксиддисмутазы и глутатионпероксидазы.

Результаты и их обсуждение. Анализируя полученные нами результаты по изучению активности ферментов антиоксидантной системы в нервных тканях глаза при моделировании гипертензии у животных со стрептозотоциновым диабетом, необходимо отметить значительное снижение потенциала системы обезвреживания активных форм кислорода.

Выводы. 1. Выявлено, что развитие офтальмогипертензии у животных с сахарным диабетом приводит к более выраженному снижению потенциала системы обезвреживания активных форм кислорода в тканях глаза по сравнению с диабетом и гипертензией у отдельных групп животных. Активность супероксиддисмутазы и каталазы в сетчатке и зрительном нерве при сочетанном развитии сахарного диабета и гипертензии была значимо ниже по сравнению с диабетическими условиями на $16,5 \%$ и $17,9 \%$ соответственно.

2. Установлено, что при совместном протекании глазной гипертензии и гипергликемии скорость обезвреживания липидных гидропероксидов в нервных элементах зрительного анализатора была значительно снижена по сравнению с нормой и животными с гипертензией. Активность глутатионпероксидазы была снижена в этих условиях на $43,2 \%$ и $32,8 \%$ соответственно. Ключевые слова: глазная гипертензия, диабет, сетчатка и зрительный нерв, каталаза, супероксиддисмутаза, глутатионпероксидаза.
\end{abstract}

На сегодняшний день актуальным является поиск арсенала лекарственных препаратов, направленных на нормализацию обменных процессов в тканях глаза с целью воздействия на дистрофические процессы, характерные для диабета (диабетическая ретинопатия) и глаукомы (нейропротекторная терапия) [1-3]. При этом эффективность лекарственной терапии определяется ее патогенетической направленностью. Поэтому уточнение вопросов патогенеза этих патологий, несмотря на их многочисленность, сохраняет свою актуальность.

В последние годы начал формироваться новый взгляд на диабетическую ретинопатию как на ней- родегенеративное заболевание глаза $[5,6,9,20]$. В патогенезе диабетической ретинопатии ведущими патогенетическими механизмами являются процессы гликирования, оксидативный стресс и другие метаболические нарушения.

Как известно, в здоровом организме оксидантные и антиоксидантные процессы сбалансированы, поэтому постоянно образующиеся свободные радикалы нейтрализуются. У больных сахарным диабетом это равновесие сдвигается в сторону избыточной продукции свободных радикалов и, соответственно, ослаблению защитных механизмов. Эти процессы запускают целый каскад метаболических, биофизических, иммуно- 
логических нарушений, приводящих к развитию диабетических осложнений как со стороны органа зрения, так и других систем организма. В этих условиях состояние антиоксидантной системы и, в первую очередь, ее энзиматической компоненты является чрезвычайно важным моментом в патогенезе всех диабетических поражений органов и тканей организма [12].

Одним из механизмов, вызывающих окислительные разрушительные процессы в организме, является пониженная активность антиоксидантной защиты, представленная рядом ферментов и коферментов (глутатионом, глутатионпероксидазой, супероксиддисмутазой, каталазой), а также рядом витаминов (А, группой $\mathrm{B}, \mathrm{C}, \mathrm{E})$ и другими антиоксидантами (таурином, каротином, кверцетином и др.) $[13,15,17,19,22]$.

Первичную глаукому в настоящее время многие авторы также рассматривают как нейродегенеративное заболевание органа зрения, определяя ее как глаукомную оптическую нейропатию [2].

Следует отметить, что, согласно существующей на сегодня метаболической концепции патогенеза глаукомной оптической нейропатии, особую роль играют окислительный стресс и эксайтотоксическое повреждение третьего нейрона сетчатки. Важная роль также отводится патологическим процессам при участии активированной нейроглии, которая, в условиях гипоксии, продуцирует избыточное количество токсических метаболитов, оказывающих повреждающее действие на нейроны сетчатки и аксоны зрительного нерва. При глаукоме наиболее изученными метаболическими процессами являются процессы перекисного окисления липидов. Участие процессов свободнорадикального окисления в патогенезе глаукомы принято рассматривать в двух аспектах $[4,11]$.

Во-первых, это те патологические изменения с участием активных форм кислорода и их метаболитов, которые приводят к деструктивным процессам в дренажном аппарате глаза [16].

Во-вторых, это - цитотоксическое действие свободных радикалов на сетчатку и зрительный нерв.

В физиологическом состоянии активность процессов пероксидации эффективно контролируется системой антиоксидантной защиты, которая выполняет охранительную роль, обеспечивая стабильно низкий уровень свободных радикалов в клетке, поскольку длительное повышение липопероксидации свободных радикалов вызывает необратимые изменения различных компонентов клетки и тканей. Даже кратковременный дефицит антиоксидантов не проходит для организма бесследно. Так, например, снижение уровня прямого жирорастворимого антиоксиданта токоферола приводит к значительному увеличению в тканях и крови организма продуктов перекисного окисления липидов - диеновых конъюгатов и малонового диальдегида [16].
Таким образом, в указанных двух нейродегенеративных заболеваниях органа зрения (диабетическая ретинопатия и глаукоматозная оптическая нейропатия) общим патогенетическим механизмом является, прежде всего, активация процессов пероксидации за счет усиленной генерации активных форм кислорода и ослабление антиоксидантной системы.

В этой связи считаем перспективным изучение состояния энзиматической системы детоксикации свободных радикалов супероксиддисмутазы, каталазы, глутатионпероксидазы в нервной ткани глаза при гипертензии на фоне экспериментального диабета.

Цель исследования - изучить активность ферментов антиоксидантной системы в нейрональных тканях глаза при моделировании гипертензии у животных со стрептозотоциновым диабетом.

Материалы и методы. Экспериментальные исследования проводились на 32 кроликах (массой 2,5-3,2 кг). Работа с животными проводилась согласно требованиям «Европейской конвенции о защите позвоночных животных, используемых для экспериментальных и других целей» (Страсбург, 1986), «Правил выполнения работ с использованием экспериментальных животных», утвержденных Приказом М3 Украины и Законом Украины «О защите животных от жестокого обращения» (№ 1759-VI от 15.12.2009).

Подопытные животные были разделены на четыре группь: 1-ая -контрольная группа (8 кроликов); 2-ая опытная группа, животные с диабетом в условиях гипертензии (10 кроликов); 3-я - опытная группа, животные с диабетом (7 кроликов); 4-ая - опытная группа, животные с гипертензией (7 кроликов). Исследования метаболических показателей проводили в экспериментальных группах на двух сроках наблюдения - через 3 недели и через 6 недель после воспроизведения офтальмогипертензии.

Все животные перед экспериментом и в ходе эксперимента подвергались измерению внутриглазного давления под местной анестезией $0,5 \%$-м раствором проксиметакаина гидрохлорида (Алкаина) с использованием пневмотонометра TOPCON CT-80.

Для моделирования гипертензии $[18,23]$ в переднюю камеру глаз подопытных животных вводились 0,25 мл 2\%-го раствора метилцеллюлозы. При воспроизведении офтальмогипертензии животным применяли общую анестезию путем введения кетамина 50 мг/кг, местно в конъюнктивальный мешок за 1 минуту до инъекции вводили глазные капли - 0,5\%-й раствор проксиметакаина гидрохлорида (Алкаин). Немедленно после инъекции кролики проверялись путем биомикроскопии для оценки травмы, возможно вызываемой в процессе инъекции.

Диабет вызывали путем внутривенной инъекции стрептозотоцина в дозе 65 мг на 1 кг веса тела $[14,21]$.

В конце исследования все кролики были выведены из эксперимента с помощью летальной дозы пенто- 
барбитола натрия (100 мг на к2, вводимого в маргинальную ушную вену).

В тканях изолированной сетчатки и зрительного нерва производили определение активности каталазы, супероксиддисмутазы и глутатионпероксидазы.

Принцип метода определения супероксиддисмутазы состоит в определении степени торможения определяемой СОД реакции восстановления нитросинего тетразолия супероксидными радикалами. Гомогенат готовили в соотношении 1:10 (вес ткани : объем среды для гомогенизации). Для определения активности СОД 0,02 мл тканевого экстракта или 0,02 мл камерной влаги вводили в 3 мл инкубационной среды, содержащей 0,41 мМ нитросинего тетразолия, 0,33 мМ ЭДТА, 0,01 мМ N-метилфеназония метилсульфата. Измеряли оптическую плотность раствора на спектрофотометре при длине волны 540 нм, затем добавляли в кювету спектрофотометра 0,1 мл 0,8 мМ НАД·Н, перемешивали и оставляли в темноте на 10 мин, после чего повторно измеряли оптическую плотность. О реакции судили по разнице между первым и вторым показаниями спектрофотометра. За единицу активности принимали 50\% торможения реакции восстановления нитросинего тетразолия. Активность фермента выражали в условных единицах на грамм ткани.

Коэффициент вариации метода составлял 6,2\% $[8,10]$.

Принцип метода определения каталазы основан на способности перекиси водорода образовывать с солями молибдена стойкий окрашенный комплекс.

Ход определения. Реакцию запускали добавлением материала для исследований 0,1 мл гомогената и 0,05 мл камерной влаги, приготовленного на 0,05М трис-НCl-буфере $(\mathrm{pH} 7,8)$ к 2 мл 0,03\% раствора перекиси водорода. Гомогенат готовили в соотношении 1:10 (вес ткани : объем среды для гомогенизации). В холостую пробу вместо материала вносили 0,1 мл дистиллированной воды. Реакцию останавливали через 10 мин добавлением 1 мл 4\%-ого молибдата аммония. Интенсивность развившейся окраски измеряли на спектрофотометре «Спекол-210» при длине волны 410 нм против контрольной пробы, в которую вместо перекиси водорода вносили 2 мл воды. Активность каталазы выражали в мккат/2 ткани.

Коэффициент вариации метода составлял 8,7\% [8].

Активность глутатионпероксидазы определяли спектрофотометрически по скорости образования окисленного глутатиона с помощью сопряженной реакции с НАДФН-зависимым ферментом глутатионредуктазы, регистрируя изменение оптической плотности при окислении НАДФН.

Ход определения. Гомогенат готовили в соотношении 1:10 (вес ткани : объем среды для гомогенизации). Для определения в пробирку вносили 0,1 мл раствора, содержащего в 0,1 моль К-фосфатного буфера (рН 7,5) 2 ммоль ЭДТА и 10 ммоль восстанов- ленного глутатиона и 0,1 мл биологического материала для исследования. Через 3 мин инкубации при $25^{\circ} \mathrm{C}$ вносили 0,01 мл 40 ммоль раствора гидроперекиси трет-бутила. Спустя 5 мин в реакционную смесь добавляли 3,84 мл 0,5 моль трис-НС1 буфера (pH 7,7) с 1 моль ЭДТА. 2 мл полученного раствора сразу после этого вносили в кювету и добавляли 0,05 мл 3,5 ммоль раствора НАДФН и 0,02 мл глутатионредуктазы (0,06 ед.). Быстро перемешивали и определяли изменение оптической плотности при длине волны излучение 340 н $M$ в течение 1 мин на спектрофотометре «Спекол-210». Активность фермента выражали в нкат/мг белка.

Коэффициент вариации метода составлял 1,8\% [10].

Полученные данные подвергались математической обработке с помощью пакета SPSS 11.0 [7].

Результаты и их обсуждение. Данные о влиянии глазной гипертензии на активность антиоксидантных ферментов в сетчатке и зрительном нерве при экспериментальном диабете представлены в таблице.

Как видно из представленных данных, активность глутатионпероксидазы в сетчатке и зрительном нерве исследуемых животных с диабетом и гипертензией была снижена во все периоды наблюдения, составляя в 1 -й срок - 70,54\%, т.е. 349,92 $\pm 20,07$ мккат/2 $(\mathrm{p}<0,001)$; во 2-й срок активность фермента понизилась до 56,8\%, что составило 282,35 $\pm 15,40$ мккат/ح (p<0,001) по отношению к норме 496,45 $\pm 24,80$ мккат/2.

Активность глутатионпероксидазы в сетчатке и зрительном нерве кроликов при развитии экспериментального диабета в 1-й период наблюдения понизилась до $388,79 \pm 20,40$ мккат/2, что составило

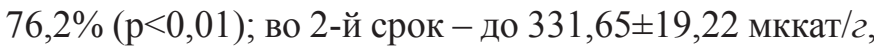
т.е. уменьшилась до $65,0 \%$ по отношению к норме $510,23 \pm 25,47$ мккат/2 $(\mathrm{p}<0,01)$.

При сравнении активности глутатионпероксидазы в сетчатке и зрительном нерве животных с диабетом и гипертензией выявили тенденцию к понижению ее активности в сравнении с группой животных с диабетом без гипертензии. В первый срок активность фермента была ниже на 10,0\%, во второй срок - на 14,9\%.

В то же время активность глутатионпероксидазы в сетчатке и зрительном нерве в группе животных с гипертензией не столь значительно понижалась - до 92,4\%,

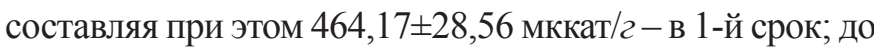
$83,6 \%$, т.е. $419,96 \pm 29,40$ мккат/2 - во 2-й срок наблюдения сравнительно с нормой $-502,35 \pm 30,40$ мккат/2.

При сопоставлении данных двух опытных групп (2-й и 4-й) можно отметить, что активность глутатионпероксидазы в сетчатке и зрительном нерве у животных с диабетом и гипертензией понижалась в гораздо большей степени по сравнению с данными, когда гипертензию вызывали у животных без диабета. Так, в первый срок снижение составило 24,6\% $(\mathrm{p}<0,01)$, во второй срок $-32,8 \%,(\mathrm{p}<0,01)$. 
Таблица

Влияние гипертензии на активность антиоксидантных ферментов в сетчатке и зрительном нерве при экспериментальном диабете у кроликов $(\mathrm{n}=7-10)$

\begin{tabular}{|c|c|c|c|c|c|}
\hline \multirow{2}{*}{$\begin{array}{c}\text { Биохимические } \\
\text { показатели }\end{array}$} & \multirow{2}{*}{ Группы животных } & \multirow{2}{*}{$\begin{array}{c}\text { Cтатистические } \\
\text { показатели }\end{array}$} & \multicolumn{3}{|c|}{ Условия эксперимента } \\
\hline & & & норма & 1-й срок & 2-й срок \\
\hline \multirow[t]{3}{*}{$\begin{array}{c}\text { глутатион-пероксидаза } \\
\text { (мккат/2) }\end{array}$} & диабет+гипертензия & $\begin{array}{c}\mathrm{M} \pm \mathrm{m} \\
\mathrm{p} \\
\% \\
\mathrm{p}_{1} \\
\%_{1} \\
\mathrm{p}_{2} \\
\%_{2} \\
\end{array}$ & $\begin{array}{c}496,45 \pm 24,80 \\
- \\
100,0 \\
>0,05 \\
97,3 \\
>0,05 \\
98,8 \\
\end{array}$ & $\begin{array}{c}349,92 \pm 20,07 \\
<0,001 \\
70,5 \\
>0,05 \\
90,0 \\
<0,01 \\
75,4 \\
\end{array}$ & $\begin{array}{c}282,35 \pm 15,40 \\
<0,001 \\
56,8 \\
>0,05 \\
85,1 \\
<0,01 \\
67,2\end{array}$ \\
\hline & диабет & $\begin{array}{l}\mathrm{M} \pm \mathrm{m} \\
\mathrm{p}\end{array}$ & $\begin{array}{c}510,23 \pm 25,47 \\
-\end{array}$ & $\begin{array}{l}388,79 \pm 20,40 \\
\quad<0,01\end{array}$ & $\begin{array}{c}331,65 \pm 19,22 \\
\quad<0,001\end{array}$ \\
\hline & гипертензия & $\begin{array}{l}\mathrm{M} \pm \mathrm{m} \\
\mathrm{p}\end{array}$ & $\begin{array}{c}502,35 \pm 30,40 \\
-\end{array}$ & $\begin{array}{l}464,17 \pm 28,56 \\
\quad>0,05\end{array}$ & $\begin{array}{l}419,96 \pm 29,40 \\
\quad>0,05\end{array}$ \\
\hline \multirow[t]{3}{*}{$\begin{array}{c}\text { супероксиддисмутаза } \\
\text { (усл. ед./2) }\end{array}$} & диабет+гипертензия & $\begin{array}{c}\mathrm{M} \pm \mathrm{m} \\
\mathrm{p} \\
\% \\
\mathrm{p}_{1} \\
\%_{1} \\
\mathrm{p}_{2} \\
\%_{2} \\
\end{array}$ & $\begin{array}{c}35,27 \pm 1,90 \\
- \\
100,0 \\
>0,05 \\
101,3 \\
>0,05 \\
100,7 \\
\end{array}$ & $\begin{array}{c}21,16 \pm 1,35 \\
<0,001 \\
60,0 \\
>0,05 \\
88,4 \\
<0,05 \\
79,3 \\
\end{array}$ & $\begin{array}{c}17,42 \pm 1,10 \\
<0,001 \\
49,4 \\
<0,05 \\
83,5 \\
<0,01 \\
72,5 \\
\end{array}$ \\
\hline & диабет & $\begin{array}{c}\mathrm{M} \pm \mathrm{m} \\
\mathrm{p}\end{array}$ & $\begin{array}{c}34,82 \pm 1,84 \\
-\end{array}$ & $\begin{array}{l}23,95 \pm 1,47 \\
\quad<0,001\end{array}$ & $\begin{array}{c}20,86 \pm 1,15 \\
<0,001\end{array}$ \\
\hline & гипертензия & $\begin{array}{c}\mathrm{M} \pm \mathrm{m} \\
\mathrm{p}\end{array}$ & $\begin{array}{c}35,04 \pm 2,16 \\
-\end{array}$ & $\begin{array}{c}26,70 \pm 1,74 \\
\quad<0,05\end{array}$ & $\begin{array}{c}24,04 \pm 1,82 \\
<0,01\end{array}$ \\
\hline \multirow[t]{3}{*}{$\begin{array}{l}\text { каталаза } \\
\text { (мккат/2) }\end{array}$} & диабет+гипертензия & $\begin{array}{c}\mathrm{M} \pm \mathrm{m} \\
\mathrm{p} \\
\% \\
\mathrm{p}_{1} \\
\%_{1} \\
\mathrm{p}_{2} \\
\%\end{array}$ & $\begin{array}{c}44,87 \pm 2,52 \\
- \\
100,0 \\
>0,05 \\
98,9 \\
>0,05 \\
99,4\end{array}$ & $\begin{array}{c}31,65 \pm 2,07 \\
<0,01 \\
70,5 \\
>0,05 \\
87,2 \\
<0,05 \\
80,1\end{array}$ & $\begin{array}{c}26,64 \pm 1,96 \\
<0,001 \\
59,4 \\
<0,05 \\
82,1 \\
<0,01 \\
73,4\end{array}$ \\
\hline & диабет & $\begin{array}{c}\mathrm{M} \pm \mathrm{m} \\
\mathrm{p}\end{array}$ & $\begin{array}{c}45,38 \pm 2,40 \\
- \\
\end{array}$ & $\begin{array}{c}36,30 \pm 1,82 \\
\quad<0,01\end{array}$ & $\begin{array}{c}32,45 \pm 1,70 \\
<0,001\end{array}$ \\
\hline & гипертензия & $\begin{array}{c}\mathrm{M} \pm \mathrm{m} \\
\mathrm{p}\end{array}$ & $\begin{array}{c}45,12 \pm 2,90 \\
-\end{array}$ & $\begin{array}{c}39,52 \pm 2,14 \\
>0,05\end{array}$ & $\begin{array}{c}36,28 \pm 2,20 \\
<0,05\end{array}$ \\
\hline
\end{tabular}

Примечания:

p - уровень значимости различий данных по отношению к группе “норма";

$\mathrm{p}_{1}$ - уровень значимости различий данных по отношению к группе “диабет”;

$\mathrm{p}_{2}$ - уровень значимости различий данных по отношению к группе “гипертензия”

Активность супероксиддисмутазы в сетчатке и зрительном нерве исследуемых животных с диабетом и гипертензией снижалась во все периоды наблюдения, составляя в 1-й срок $-60,0 \%$, т.е. $21,16 \pm 1,35$ усл.ед../2 ( $<0,001)$; во 2-й срок исследуемый показатель понизился до $49,4 \%$, что составило $17,42 \pm 1,10$ усл.ед../2 ( $<0,001)$ по сравнению с нормой $-35,27 \pm 1,90$ усл.ед../2.

Изучая активность супероксиддисмутазы в сетчатке и зрительном нерве кроликов при развитии стрептозотоцинового диабета, можно отметить, что в 1-й срок ее показатели понизились до 23,95 $\pm 1,47$ усл. ед../2, что составило $68,8 \%(\mathrm{p}<0,001)$; во 2 -й срок до $20,86 \pm 1,15$ усл.ед../2, т.е. уменьшилась до $59,9 \%$ по отношению к норме $-34,82 \pm 1,84$ усл.ед../2 ( $<<0,001)$.

Исследования активности супероксиддисмутазы в сетчатке и зрительном нерве исследуемых живот- ных с диабетом и гипертензией выявили понижение ее активности по сравнению с группой животных с диабетом без гипертензии. Так, в 1-й срок активность фермента уменьшилась на $11,6 \%$, во 2-й срок - на $16,5 \%(p<0,05)$.

Активность супероксиддисмутазы в сетчатке и зрительном нерве у животных с гипертензией была снижена до $76,2 \%$, составляя при этом $26,70 \pm 1,74$ усл. ед./2 - в 1-й срок $(\mathrm{p}<0,05)$; до $68,6 \%$, т.е. $24,04 \pm 1,82$ усл.ед./2 - во 2-й период наблюдения $(\mathrm{p}<0,01)$ сравнительно с нормой $-35,04 \pm 2,16$ усл.ед./2.

Результаты при изучении активности супероксиддисмутазы в сетчатке и зрительном нерве животных с диабетом в условиях развития гипертензии выявили понижение ее показателей по сравнению с группой животных с гипертензией без диабета. Так, в 1-й срок 
активность фермента снизилась на 20,7\% ( $<00,05)$; во 2-й срок - на 27,5\% $(\mathrm{p}<0,01)$.

Активность каталазы в сетчатке и зрительном нерве исследуемых животных с диабетом и гипертензией была снижена во все периоды наблюдения, составляя в 1 -й срок $70,5 \%$, т.е. $31,65 \pm 2,07$ мккат $/ 2(\mathrm{p}<0,01)$; во 2 -й срок активность изучаемого фермента понижалась до $59,4 \%$, что составило $26,64 \pm 1,9$ мккат/2 ( $<0,001)$ отно-

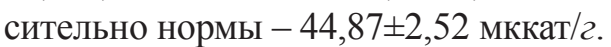

В 1-й срок наблюдения активность каталазы в сетчатке и зрительном нерве кроликов с экспериментальным диабетом была понижена до $36,30 \pm 1,82$ мккат/2, что составило $80,0 \%(\mathrm{p}<0,01)$; во 2-й срок развития диабета активность изучаемого фермента составила $32,45 \pm 1,70$ мккат/ $/ 2(p<0,001)$ по отношению к норме $-45,38 \pm 2,40$ мккат/2.

Из полученных нами результатов следует, что активность каталазы в сетчатке и зрительном нерве исследуемых животных с диабетом в условиях развития гипертензии во все сроки исследования уменьшалась по сравнению с группой животных с диабетом без гипертензии. В 1-й срок понижение составило $12,8 \%$, во 2-й срок-7,9\% $(\mathrm{p}<0,05)$.

При экспериментальной гипертензии активность каталазы в сетчатке и зрительном нерве у исследуемых животных снижалась до 90,3\%, составляя при этом $25,41 \pm 1,44$ мккат/2 в 1-й срок; до $82,6 \%$, т.е. $23,24 \pm 1,48$ мккат/2 - во 2-й период наблюдения $(\mathrm{p}<0,05)$ сравнительно с нормой - 28,14 $\pm 1,60$ мккат/2.

Сравнивая две опытные группы, можно отметить, что активность каталазы в сетчатке и зрительном нерве у животных с диабетом и гипертензией понижалась в большей степени по сравнению с данными, полученными при гипертензии, вызываемой у животных без диабета. Так, в 1-й срок уменьшение составило $19,9 \%$ $(\mathrm{p}<0,05)$, во 2-й срок $-26,6 \%$, при $\mathrm{p}<0,01$.

Анализируя полученные нами результаты активности ферментов антиоксидантной системы в нейрональных тканях глаза при моделировании гипертензии у животных со стрептозотоциновым диабетом, необходимо отметить значительное снижение потенциала системы обезвреживания как активных форм кислорода, так и свободных радикалов органических липоперекисей.

Так, в этих условиях активность супероксиддисмутазы и каталазы в нервных тканях зрительного анализатора была снижена по сравнению с нормой на $50,6 \%$ и $40,6 \%$ соответственно, что также было значимо ниже по сравнению с показателями супероксиддисмутазы и каталазы у животных с диабетом. Эти ферменты являются дезактиваторами активных форм кислорода, поэтому результатом снижения их активности является увеличение уровня в нервной ткани таких радикалов, как гидроксид-ион, гидроген пероксид, супероксид.
Активность глутатионпероксидазы при развитии гипертензии у животных с сахарным диабетом также существенно была снижена по сравнению с нормой и в гораздо меньшей степени по сравнению с животными со стрептозотоциновым диабетом. Этот фермент, наряду с деактивацией перекиси водорода, участвует в разрушении органических липидных пероксидов. Поэтому низкая активность этого фермента вызывает снижение у этих животных возможностей к обезвреживанию активных форм кислорода и ведет к росту содержания в нервной ткани глаза не только низкомолекулярных радикалов, но и липидных гидроперекисей.

Таким образом, нервные клетки зрительного анализатора при гипертензии в условиях сахарного диабета оказывались наиболее незащищенными от окислительного стресса, который был инициирован как за счет нарушения метаболических процессов при диабете, так и за счет гипоксического состояния при гипертензии $[9,11,12,15,16]$.

Этот факт, несомненно, можно рассматривать как существенное патогенетическое звено механизма усиления нейродегенеративных процессов в зрительном анализаторе при сахарном диабете в условиях дополнительного воздействия глазной гипертензии.

\section{Выводы}

1. Развитие офтальмогипертензии у животных с сахарным диабетом приводит к более выраженному снижению потенциала системы обезвреживания активных форм кислорода в тканях глаза по сравнению с группами животных раздельно с диабетом и глазной гипертензией. Активность антиоксидантных ферментов супероксиддисмутазы и каталазы в сетчатке и зрительном нерве при сочетанном развитии сахарного диабета и гипертензии была значимо ниже по сравнению с диабетическими условиями - на $16,5 \%$ и $17,9 \%$ соответственно.

2. При совместном воздействии офтальмогипертензии и гипергликемии скорость обезвреживания липидных гидропероксидов в нервных элементах зрительного анализатора была значительно снижена по сравнению с нормой и животными с гипертензией. Активность глутатионпероксидазы была снижена в этих условиях на $43,2 \%$ и $32,8 \%$ соответственно.

\section{Литература}

1. Анина E. A. Глаукома у взрослого населения Украины / Е. А. Анина, К. В. Мартопляс // Філатовські читання: наук.-практ. конф. офтальмол. $з$ міжнар. участю: тези доп. - Одеса, 2009. - С. 80-81.

2. Еричев В. П. Глаукома и нейродегенеративные заболевания / В. П. Еричев, В. П. Туманов, Л. А. Панюшкина // Глаукома. - 2012. - № 1.- С. 62-68.

3. Ефимов А. Диабетическая невропатия / А. Ефимов, Н. Скоробонская, Н. Зуева // Ліки України. - 2005. - № 3. - C. 21-25. 
4. Кравчук E. А. Роль свободнорадикального окисления в патогенезе заболеваний глаз / Е. А. Кравчук // Вестник офтальмологии. - 2004. - № 5. C. $48-51$.

5. Леус Н. Ф. Метаболические механизмы развития и перспективы медикаментозного лечения диабетической ретинопатии / Н. Ф. Леус // Офтальмол. журн. - 2003. - № 5. - С. 75-80.

6. Мальцев Э. В. Нейродегенерация и нейропротекция при диабетической ретинопатии / Э. В. Мальцев, А. В. Зборовская, А. Э. Дорохова // Офтальмол. журнал. - 2012. - № 1. - С. 67-72.

7. Наследов A. SPSS-компьютерный анализ данных в психологии и социальных науках. / А. Наследов. - СПб.: Питер, 2005. - 416 с.

8. Новые методы биохимического анализа. - Изд. Ленинградского универ., 1991. - 395 с.

9. Barber A. J. A new view of diabetic retinopathy: a neurodegenerative disease of the eye. / A. J. Barber // Prog. In Neuro-Psychopharm. \& Biol. Psych. - 2003. - Vol. 27. - P. 283 - 290.

10. Bergmeyer $H$. U. Methoden der enzymatischen Analyse / Herausgegeben von H. U. Bergmeyer. - Berlin, 1986. - $2220 \mathrm{p}$.

11. Chrysostomov $V$. Oxidative stress and mitochondrial dysfunction in glaucoma / V. Chrysostomov, F. Rezania, I. A. Trounce, J. G. Crowston // Curr. Opin. Pharmacol. - 2013. - Vol. 13. - P. 12-15.

12. Feng B. Oxidative-stress-induced epigenetic changes in chronic diabetic complications / B. Feng, M. A. Ruiz, S. Chakrabarti // Can. J. Physiol. Pharmacol. 2013. - Vol. 91. - P. 213-220.

13. Jandric-Balen $M$. Antioxidant enzymes activity in patients with peripheral vascular disease, with and without presence of diabetes mellitus / M. Jandric-Balen, V.Bozikov, D. Bistrovic // Coll. Antropol. - 2003. - Vol. 27. - P. 735-743.

14. Kedar P. Effect of Jambolan seed treatment on blood sugar lipids and urea in streptozotocine induced diabetes in rabbits / P. Kedar, C. H. Chakrabarti // Indian
J. Physiology Pharmacology. - 1983. - Vol. 27. - P. 135-140.

15. Kowluru R. A. Role of mitochondrial superoxide dismutase in the development of diabetic retinopathy / R. A. Kowluru, L. Atasi, Y. S. Ho // Invest. Ophthalmol. Vis. Sci. - 2006. - Vol. 47. - P. 1594-1599.

16. Kumar D. M. Oxidative stress in glaucoma: a burden of evidence / D. M. Kumar, N. Agarwal // J Glaucoma. - 2007. - Vol. 16. - P. 334-343.

17. Kurtul N. Leukocyte lipid peroxidation, superoxide dismutase and catalase activities of type 2 diabetic patients with retinopathy / N. Kurtul, E. Bakan, H. Aksoy, O. Baykal // Acta Medica (Hradec Kralove). 2005. - Vol. 48. - P. 35-38.

18. Lambiase $A$. Nerve growth factor (NGF) reduces and NGF antibody exacerbates retinal damage induced in rabbit by experimental ocular hypertension / A. Lambiase, M. Centofanti, A. Micera // Graefe's Arch. Clin. Exp. Ophthalmol. - 1997. - Vol. 235. P. 780-785.

19. Muchova J. Antioxidant systems in polymorphonuclear leucocytes of Type 2 diabetes mellitus / J. Muchova, A. Liptakova, Z. Orzaghova // Diabet. Med. - 1999. - Vol. 16. - P. 74-78.

20. Speicher M. A. Pharmacologic therapy for diabetic retinopathy / M. A. Speicher, R. P. Danis, M. Criswell // Expert Opion Emerg Drugs. - 2003. - Vol. 8 (1). P. 239-250.

21. Wang J. Creating a long-term diabetic rabbit model/ J. Wang, R. Wan, Y. Mo // Exp. Diabetes res. - 2010. - Vol. 6. - P. 1-10.

22. Winkler $R$. Alterations of antioxidant tissue defense enzymes and related metabolic parameters in streptozotocin-diabetic rats-effects of iodine treatment / R. Winkler, M. Moser // Wien Klin. Wochenschr. 1992. - Vol. 104. - P. 409-413.

23. Zhu M. D. Development of experimental chronic intraocular hypertension in the rabbit / M. D. Zhu, F. Y. Cai // Australian and New Zeland J Ophthalmol. - 1992. - Vol. 20. - P. 225-234.

\title{
СТАН АНТИОКСИДАНТНОЇ СИСТЕМИ В НЕЙРОНАЛЬНИХ ТКАНИНАХ ОКА ПРИ МОДЕЛЮВАННІ ОФТАЛЬМОГІПЕРТЕНЗІЇ У ТВАРИН ЗІ СТРЕПТОЗОТОЦИНОВИМ ДІАБЕТОМ
}

\author{
В. Р. Юревич
}

Пошук лікарських препаратів, спрямованих на нормалізацію обмінних процесів у тканинах ока при цукровому діабеті та гіпертензії, $є$ вкрай актуальним. При цьому ефективність лікарської терапії визначається іiі патогенетичною спрямованістю. Тому уточнення питань патогенезу цих патологій зберігає свою важливість.

Мета дослідження. Вивчити стан антиоксидантної системи в тканинах ока при моделюванні гіпертензії (експериментальної глаукоми) у тварин зі стрептозотоциновим діабетом.

Матеріали та методи. Дослідження проводилися на 32 кролях. Піддослідні тварини були розділені на чотири групи: 1-a - контрольна група (8 кролів); 2- $a$ - дослідна група, тварини з діабетом в умовах гіпертензії (10 кролів); 3-я - дослідна група, тварини з діабетом (7 кролів); 4- $a$ - дослідна група, тварини з гіпертензією (7 кролів). У тканинах ізольованої сітківки та зорового нерва визначали активність каталази, супероксиддисмутази і глутатіонпероксидази. 
Результати та їх обговорення. Аналізуючи отримані нами результати 3 вивчення активності ферментів антиоксидантної системи в нервових тканинах ока при моделюванні офтальмогіпертензії у тварин зі стрептозотоциновим діабетом, необхідно звернути увагу на значне зниження потенціалу системи знешкодження активних форм кисню.

Висновки. 1. Виявлено, що розвиток офтальмогіпертензії у тварин з цукровим діабетом призводить до більш вираженого зниження потенціалу системи знешкодження активних форм кисню у нервових тканинах ока в порівнянні з групами тварин з діабетом і гіпертензією. Активність супероксиддисмутази і каталази в сітківці і зоровому нерві при одночасному розвитку цукрового діабету і офтальмогіпертензії була значущо нижча в порівнянні $з$ діабетичними умовами - на 16,5\% і 17,9\% відповідно.

2. Встановлено, що при спільному впливі офтальмогіпертензії та гіперглікемії швидкість знешкодження ліпідних гідропероксидів у нервових елементах зорового аналізатора була значно знижена в порівнянні 3 нормою у тварин з гіпертензією. Активність глутатіонпероксидази була знижена в цих умовах на 43,2\% і $32,8 \%$ відповідно.

Ключові слова: гіпертензія ока, діабет, сітківка та зоровий нерв, каталаза, супероксиддисмутаза, глутатіонпероксидаза.

\title{
ANTIOXIDANT SYSTEM IN THE NERVOUS TISSUES OF THE EYE IN THE OPHTHALMOHYPERTENSION IN ANIMALS WITH STREPTOZOTOCIN DIABETES
}

\author{
V. R. Yurevych \\ Lviv National Medical University named after Danylo Halytskiy of the Ministry of Public Health of Ukraine \\ Lviv, Ukraine
}

Introduction. Relevant is the search for drugs to normalize metabolic processes in the tissues of the eye in diabetes and ophthalmohypertension.

Herewith, the effectiveness of drug therapy is determined by its pathogenetic orientation. Therefore, clarification of the pathogenesis of these pathologies remains consistent.

Purpose. Examine the state of the antioxidant system in the tissues of the eye in the simulation hypertension (experimental glaucoma) in animals with streptozotocin diabetes.

Methods. Studies were conducted on 32 rabbits. The experimental animals were divided into four groups: the first group - control group ( 8 rabbits), the second - the experimental group of animals with diabetes in terms of hypertension (10 rabbits), the third - the experimental group of animals with diabetes ( 7 rabbits), the fourth - the experimental group animals with hypertension ( 7 rabbits). The activity of catalase, superoxide dismutase and glutathione peroxidase was identified in isolated tissues of the retina and optic nerve tissue.

Results. Analyzing the study results of the activity of antioxidant enzymes in the neuronal tissues of the eye in the modeling hypertension in animals with streptozotocin diabetes, a significant reduction in the capacity of neutralization of reactive oxygen species was traced.

Conclusions. 1. It was found out that the development of ophthalmohypertension in animals with diabetes leads to a more pronounced reduction in the capacity of neutralization of reactive oxygen species in the eye tissues compared with diabetes and ophthalmohypertension in separate groups of animals. Superoxide dismutase and catalase in the retina and optic nerve with concomitant development of hypertension and diabetes was significantly lower by $16.5 \%$ and $17.9 \%$ respectively compared with diabetic conditions.

2. It was found out that, when combined with the effects of ocular hypertension and hyperglycemia, the rate of neutralization of lipid hydroperoxides in the neural elements of the visual analyzer was significantly reduced compared with the normal and hypertensive animals. Glutathione peroxidase activity was reduced under these conditions by $43.2 \%$ and $32.8 \%$ respectively.

Key words: ocular hypertension, diabetes, retina and optic nerve, superoxide dismutase, catalase, glutathione peroxidase.

Стаття надійшла до редакції 07.08.2018 p. 